\title{
An Extremely Reliable Prevention of Cancer
}

\section{Kimihiko Okazaki*}

Okazaki Medical Clinic, Ukyoku, Kyoto, Japan

*Corresponding author: Kimihiko Okazaki, Okazaki Medical Clinic, Ukyoku, Kyoto, Japan, Tel: +81-75-314-8123; E-mail: ma13081x@ma1.seikyou.ne.jp

Received date: December 20, 2017; Accepted date: December 21, 2017; Publication date: December 28,2017

Citation: Okazaki K (2017) An Extremely Reliable Prevention of Cancer. J Prev Med Vol.3 No.1: 2.

Copyright: (C) 2017 Okazaki K. This is an open-access article distributed under the terms of the Creative Commons Attribution License, which permits unrestricted use, distribution and reproduction in any medium, provided the original author and source are credited.

\section{Opinion}

In 1985, Kochi et al. [1,2] reported a novel anti-tumor agent after acquiring a Japanese Patent in 1969. According to his patent, 4-Hydroxybenzaldehyde is a water-soluble anti-tumor agent without any side-effects. Most, if not all, of so-called antitumor agents are incapable of ceasing carcinogenesis. In other words, they are only able to control multiplications of malignant tumor cells. Still in other words, they inhibit divisions of malignant cells. Therefore, they cannot be used for cancerprevention. Kochi passed away in 2004 at the age of 92 without leaving any information about the action-mechanism of the compound. However, participation of Tyrosine kinase in carcinogenesis was reported in 1989 [3]. Concepts that compounds of structures similar to those of substrates of enzymes are able to inhibit the activities of the enzymes have been established as early as 1962 [4].

It is evident that the action-mechanism of the compound is competitive inhibition of Tyrosine kinase. There are three common groups in molecular formulas of both compounds;
Tyrosine and 4-Hydroxybenzaldehyde; Benzene nucleus, Carbonyl group, and Hydroxyl group. A detailed explanation of competitive inhibition is that the substrate-site of the enzyme mis-recognizes the inhibitor as the substrate. In conclusion, an oral intake of aqueous solution of 4-Hydroxybenzaldehyde dissolving $1 \mathrm{~g}$ of it once in every month will prevent all cancer developments.

\section{References}

1. Kochi M, Isono N, Niwayama M, Shirakabe K (1958) Antitumor activity of a benzaldehyde derivative. Cancer Treat Rep 69: 533-537.

2. Kochi M (1969) Manufacturing process of anticancer substance. Japanese Patent.

3. Okada M, Nakagawa $H$ (1989) A protein tyrosine kinase involved in regulation of pp60c-src function. J Biol Chem 264: 20886-20893.

4. White A, Handler P, Smith EL (1968) Principles of Biochemistry. ( $4^{\text {th }}$ edn.) McGraw-Hill Book Company, New York, USA. 